\title{
DIA proteomics analysis through serum profiles reveals the significant proteins as candidate biomarkers in women with PCOS
}

Ying Yu ${ }^{1,2}$, Panli Tan², Zhenchao Zhuang ${ }^{2}$, Zhejiong Wang ${ }^{2}$, Linchao Zhu ${ }^{2}$, Ruyi Qiu ${ }^{2}$ and Huaxi Xu ${ }^{1 *}$

\begin{abstract}
Background: The aim of this study was to apply proteomic methodology for the analysis of proteome changes in women with polycystic ovary syndrome (PCOS).

Material and methods: All the participators including 31 PCOS patients and 31 healthy female as controls were recruited, the clinical characteristics data was recorded at the time of recruitment, the laboratory biochemical data was detected. Then, a data-independent acquisition (DIA)-based proteomics method was performed to compare the serum protein changes between PCOS patients and controls. In addition, Western blotting was used to validate the expression of identified proteomic biomarkers.

Results: There were 80 proteins differentially expressed between PCOS patients and controls significantly, including 54 downregulated and 26 upregulated proteins. Gene ontology and Kyoto Encyclopedia of Genes and Genomes analysis showed that downregulated proteins were enriched in platelet degranulation, cell adhesion, cell activation, blood coagulation, hemostasis, defense response and inflammatory response terms; upregulated proteins were enriched in cofactor catabolic process, hydrogen peroxide catabolic process, antioxidant activity, cellular oxidant detoxification, cellular detoxification, antibiotic catabolic process and hydrogen peroxide metabolic process. Receiver operating characteristic curves analysis showed that the area under curve of Histone $\mathrm{H} 4(\mathrm{H} 4)$, Histone H2A (H2A), Trem-like transcript 1 protein (TLT-1) were all over than 0.9, indicated promising diagnosis values of these proteins. Western blotting results proved that the detected significant proteins, including $\mathrm{H} 4, \mathrm{H} 2 \mathrm{~A}, \mathrm{TLT}-1$, Peroxiredoxin-1, Band 3 anion transport protein were all differently expressed in PCOS and control groups significantly.
\end{abstract}

Conclusion: These proteomic biomarkers provided the potentiality to help us understand PCOS better, but future studies comparing systemic expression and exact role of these candidate biomarkers in PCOS are essential for confirmation of this hypothesis.

Keywords: Proteomics analysis, Polycystic ovary syndrome, Proteome changes, Biomarkers

*Correspondence: xu_huaxi@163.com

1 Institute of Laboratory Medicine, Jiangsu Key Laboratory of Laboratory Medicine, Jiangsu University, No. 301 Xuefu Road, Zhenjiang, Jiangsu 210013, People's Republic of China

Full list of author information is available at the end of the article

\begin{abstract}
Introduction
Polycystic ovary syndrome (PCOS) is one of the most common endocrine and metabolic disorders, 5-15\% female in reproductive age live with a PCOS diagnosis worldwide. The etiopathogenesis of PCOS is complex, genetic, environmental and lifestyle interaction contribute to the etiology of PCOS. Hyperandrogenism and insulin resistance (IR) are the major characteristics of
\end{abstract}

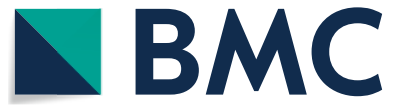

(c) The Author(s) 2021. This article is licensed under a Creative Commons Attribution 4.0 International License, which permits use, sharing, adaptation, distribution and reproduction in any medium or format, as long as you give appropriate credit to the original author(s) and the source, provide a link to the Creative Commons licence, and indicate if changes were made. The images or other third party material in this article are included in the article's Creative Commons licence, unless indicated otherwise in a credit line to the material. If material is not included in the article's Creative Commons licence and your intended use is not permitted by statutory regulation or exceeds the permitted use, you will need to obtain permission directly from the copyright holder. To view a copy of this licence, visit http://creativecommons.org/licenses/by/4.0/. The Creative Commons Public Domain Dedication waiver (http://creativecommons.org/publicdomain/zero/1.0/) applies to the data made available in this article, unless otherwise stated in a credit line to the data. 
PCOS [1]. And normally, except for the above-mentioned characteristics, the clinical features of PCOS usually including menstrual cycle irregular, ovarian abnormalities, follicular dysplasia (with multiple cystic ovarian follicles), etc. [2]. But the diagnosis of PCOS is quite difficult since the symptoms of PCOS patients are not unified. Except for the PCOS caused physical hazards in reproductive age women, PCOS also has negative effects on life quality and mental health. In the female with PCOS, the long-term risks of endometrial carcinoma, diabetes mellitus, and cardiovascular diseases also seem to be higher than the normal populations [3, 4]. Population based studies show that PCOS and thereby caused infertility are associated with lower life satisfaction, poor health status and increased psychological distress, including depression, anxiety and perceived stress [5, 6].

Proteomics is an emerging tool involves comprehensive study of qualitative and quantitative profiling of proteins present in tested samples [7]. It can systematically characterize a large-scale of dynamic changes in protein expression, which can provide basic information for the study of complex diseases. Thus allowing the capacity to unravel new mechanistic explanations and offering richer source of potential diagnostic biomarkers associated with complex metabolic disorders. In the past few years, substantial efforts have been used to study the pathogenesis of PCOS via proteomic approaches, but challenges still exist [8]. The identification of novel proteins in PCOS is of great interest for developing more precise diagnostic strategy and new therapeutic targets. Data independent acquisition (DIA) recommended with high reproducibility and high-throughput is a powerful technique in proteomics studies. The mass spectrometer in DIA systematically acquires MS/MS spectra without regard to whether a precursor signal is detected, which is in comparison to datadependent acquisition (DDA) for proteomics research [9].

In this experiment, DIA proteomic techniques was employed to explore a broad spectrum of functional proteins in PCOS patients and controls. The aim of this study was to use proteomic methodologies for the identification of biomarkers over- or under expressed in women with PCOS compared with the controls, and provide the potentiality to help us understand PCOS better.

\section{Material and methods}

\section{Regents}

UltraPure $^{\mathrm{TM}}$ Tris Hydrochloride (Tris- $\mathrm{HCl}$ ) (Invitrogen, CA, USA), Ammonium biocarbonate $\left(\mathrm{NH}_{4} \mathrm{HCO}_{3}\right)$ (Sigma-Aldrich, Shanghai, China), Trifluoroacetic Acid (TFA) (Sigma-Aldrich, Shanghai, China), DT-Dithiothreitol (DTT) (Sigma-Aldrich, Shanghai, China), Iodoacetamide (IAM) (Sigma-Aldrich, Shanghai, China),
Lysyl Endopeptidase, MS Grade (LysC) (Wako, Japan), Sequencing Grade Modified Trypsin (Trypsin) (Promega, WI, USA), SOLA $\mu$ HRP $2 \mathrm{mg} / 1 \mathrm{~mL} 96$ well plate (Thermo Scientific, Shanghai, China), Methanol, Optima ${ }^{\text {TM }}$ LC/MS Grade (Fisher Scientific, PA, USA), Acetonitrile, Optima $^{\mathrm{TM}}$ LC/MS Grade, (Fisher Scientific, PA, USA), $\mathrm{dd}_{2} \mathrm{O}$ (water from thermo ScientificTM water Purification system), High Select ${ }^{\mathrm{TM}}$ Top14 Abundant Protein Depletion Mini Spin Columns (Fisher Scientific, PA, USA).

\section{Study subjects}

All the participators including 31 PCOS patients and 31 paired healthy female controls were recruited from the Chinese Medicine Hospital of Zhejiang province (Hangzhou, China). This study received the ethical approval from the Ethics Committee of Zhejiang Provincial Hospital of Chinese Medicine [approve no. 2020-KL-15502]. All the participators signed informed consent forms before the start of the study.

The inclusion criteria for PCOS cases were: adolescent females, diagnosed with PCOS, had at least 2 years of menstrual history. And in order to exclude the luteal phase, progesterone $(\mathrm{P})$ level was less than 3.82. PCOS was diagnosed based on the recent androgen excess and Rotterdam criteria, 2003: clinical or biochemical hyperandrogenism and ovarian dysfunction: oligomenorrhea (menstrual cycle of more than 45 days) and/or polycystic ovaries on ultrasound (ovarian volume $>10 \mathrm{~mL}$ in at least one ovary) [10]. Exclusion criteria: other disorders with similar presentation (hyperprolactinemia, thyroid disorders, late-onset congenital adrenal hyperplasia, androgen-secreting ovarian or adrenal tumors, Cushing syndrome, or other related disorders) were excluded [11]. Healthy controls were volunteers with age and gender matched with PCOS patients. And no evident disease was detected in them during the course of the study.

The clinical characteristics data of the enrolled participators were recorded at the time of recruitment. After fasting for $8 \mathrm{~h}$, a venous blood sample from each participator was collected. The serum samples were stored at $-80{ }^{\circ} \mathrm{C}$ for subsequent assay.

\section{Clinical laboratory tests}

Serum concentrations of follicle-stimulating hormone (FSH), luteinizing hormone (LH), estradiol (E2), prolactin (PRL), testosterone $(\mathrm{T}), \mathrm{P}$ in all PCOS patients and control participators were detected by Immulite 2000 analyzer (Siemens Healthcare Diagnostics Products Ltd., UK) using two site chemiluminescent immunometric assays. 


\section{Clinical data analysis}

All the clinical data were computed using SPSS18.0 version software. An unpaired, two-tailed student $t$ test was performed on clinical biochemical data, the chisquare test was used for comparison of categorical variables. $p$ value $<0.05$ was considered to be statistically significant.

\section{Sample processing}

Samples were prepared following the manufacturer's instructions. The details were as following.

\section{High-abundance protein removal}

All 62 samples were depleted with top 14 high-abundant depletion spin columns (Thermo) was placed at room temperature, $10 \mu \mathrm{l}$ (about $600 \mu \mathrm{g}$ ) of serum sample was added, and incubation was carried out for $30 \mathrm{~min}$ at room temperature. The supernatant was collected by centrifugation at $1,000 \mathrm{~g}$ for $2 \mathrm{~min}$, and the volume was about $320 \mu \mathrm{l}$, the solution system was $10 \mathrm{mM}$ PBS, $0.15 \mathrm{M} \mathrm{NaCl}, 0.02 \%$ azide, $\mathrm{pH}$ 7.4.

\section{LysC/trypsin digestion}

$320 \mu \mathrm{l}$ of high-abundance protein-depleted sample was added to a $10 \mathrm{kD}$ ultrafiltration tube (Millipore), $12,000 \mathrm{~g}$, centrifuged for $10 \mathrm{~min}$; added $200 \mu \mathrm{l}$ of $8 \mathrm{M}$ Urea, $12,000 \mathrm{~g}$, centrifuged for $10 \mathrm{~min}$, repeated once, and finally $50 \mu \mathrm{l}$ of $8 \mathrm{M}$ urea were added. Then the sample was added into a 96-well plate. $10 \mathrm{mM}$ DTT solution was added and reacted at $37{ }^{\circ} \mathrm{C}$ for $30 \mathrm{~min}$; IAM solution was added to a final concentration of $20 \mathrm{mM}$, and reacted at $37^{\circ} \mathrm{C}$ for $30 \mathrm{~min}$ at room temperature in the dark for $30 \mathrm{~min}$; DTT solution was added to a final concentration of $10 \mathrm{mM}$ to quench the reaction. $1 \mu \mathrm{g}$ of LysC was added to each sample, incubate at $37{ }^{\circ} \mathrm{C}$ for $2 \mathrm{~h} ; 1 \mu \mathrm{g}$ Trypsin was then added and incubated at $37^{\circ} \mathrm{C}$ overnight; finally $10 \mu \mathrm{l}$ of $10 \%$ TFA was added to terminate the reaction.

\section{Desalting}

Add $100 \mu$ l of methanol to SoLA $\mu$ HRP plate, $600 \mathrm{~g}$, centrifuge for $1 \mathrm{~min}$; add $100 \mu \mathrm{l}$ of $80 \% \mathrm{ACN} 0.1 \%$ TFA, $1000 \mathrm{~g}$, centrifuge for $1 \mathrm{~min}$; add $200 \mu \mathrm{l}$ of $0.1 \%$ THA, $1000 \mathrm{~g}$, centrifuge for $1 \mathrm{~min}$; add the sample to SoLA $\mu$ In the HRP plate, $1000 g$, centrifuge for $2 \mathrm{~min}$; repeat loading the sample once; add $200 \mu \mathrm{l} 0.1 \%$ THA, $1000 g$, centrifuge for $2 \mathrm{~min}$ to wash the column; add $100 \mu \mathrm{l}$ $80 \%$ ACN $0.1 \%$ TFA, $1000 g$, centrifuge for $3 \mathrm{~min}$, collect the elution; the elution is concentrated in the centrifuge. The peptides were dissolved to $0.5 \mu \mathrm{g} / \mu \mathrm{l}$ with $0.1 \% \mathrm{FA}$, and loaded with $1 \mu \mathrm{g}$ of mass spectrometry for DIA analysis.

\section{LC-MS DIA proteomics analysis}

DIA proteomic analysis was performed using a Thermo U3000nano RSLC nanoLC (Thermo Fisher Scientific) with Orbitrap Fusion LumosTM quadrupole-linear ion trap-electrostatic field orbitrap high resolution mass spectrometry (Thermo Fisher Scientific, USA), data acquisition software XCalibur 4.3 (Thermo Fisher Scientific). The analysis was performed following the manufacturer's instructions, and the main parameters are as follows.

\section{Liquid chromatography}

Nano LC-UltiMateTM 3000 RSLC nano System; two Column Mode: Trap Column (Acclaim PepMap C18, $3 \mu \mathrm{m}$, $100 \AA, 75 \mu \mathrm{m} \times 2 \mathrm{~cm}$ ), Analytical Column (Acclaim PepMap C18, $2 \mu \mathrm{m}, 100 \AA$, $75 \mu \mathrm{m} \times 25 \mathrm{~cm}$ ); mobile phase: A: $0.1 \%$ formic acid in water; B: $0.1 \%$ formic acid in $80 \%$ acetonitrile; gradient: $3-8 \% \mathrm{~B}$ in $6 \mathrm{~min}, 8-30 \% \mathrm{~B}$ in $102 \mathrm{~min}$, $30-100 \%$ B in $8 \mathrm{~min}, 100-100 \% \mathrm{~B}$ in $4 \mathrm{~min}$; flow rate: $300 \mathrm{~nL} / \mathrm{min}$.

\section{Mass spectrometer}

Thermo Scientific Orbitrap Fusion Lumos; spray voltage: $2.1 \mathrm{kV}$; capillary temperature: $300{ }^{\circ} \mathrm{C}$; S-lens: $50 \%$; collision energy: $32 \% \mathrm{HCD}$; resolution setting: first level $60,000 \mathrm{~m} / \mathrm{z} 200$, two Level 30,000 m/z 200; Max IT: full MS $20 \mathrm{~ms}$, full MS/MS $54 \mathrm{~ms}$; parent ion scanning range: $\mathrm{m} / \mathrm{z}$ 350-1200; product ion scanning range: start from $\mathrm{m} / \mathrm{z}$ 200; number of windows: 70 ; isolation window: adjust the variable isolation window based on the eluted peptide $\mathrm{m} / \mathrm{z}$.

\section{Data processing and analysis}

Spectronaut X system was used for DIA proteomics data analysis. Briefly, 62 samples and QC data were imported into Spectronaut $\mathrm{X}$, targeted extracted with laboratory built serum proteomics database, and the remaining parameters were controlled by default to control FDR $<1 \%$ of peptide and protein levels. Protein intensity was calculated by Spectronaut from the average of the top3 peptide was exported. This protein intensity was imported into Perseus and Metaboanalyst for statistical analysis. $\log _{2}$ transformation, feature filtering, missing value filling, and data normalization of raw data were done before statistical analysis. S0 0.1 and FDR $p<0.05$ was used as the threshold value for differential proteins selection. PCA, cluster analysis, and correlation analysis were performed in Metaboanalyst. The up-regulated and down-regulated proteins were imported into the Protein Center (Thermo) for functional enrichment annotation of gene ontology (GO) and Kyoto Encyclopedia of Genes 
and Genomes (KEGG) with FDR $p<0.05$. Receiver operating characteristic (ROC) curves analysis was performed using SPSS software.

\section{Western blotting validation}

Based on the former DIA proteomics results and the identified significant protein biomarkers, Western blot assay was further performed to validate the significance of biomarkers in PCOS. Serum samples were homogenized in RIPA buffer containing protease inhibitor and the protein concentration was measured using a $\mathrm{BCA}$ method. $10 \%$ sodium dodecyl sulphate-polyacrylamide gel electrophoresis (SDS-PAGE) was used to separate the proteins, then the proteins were electrotransferred onto the nitrocellulose (NC) membranes. After blocking with non-fat mike for $1 \mathrm{~h}$ and washed with Tris-buffered saline containing Tween 20 (TBST), the membranes were probed with the primary antibodies against Histone $\mathrm{H} 4$ (H4, Affinity, dilution 1:2000), Histone H2A (H2A, Affinity, dilution 1:1000), Trem-like transcript 1 protein (TLT1 , R\&D systems, $0.1 \mu \mathrm{g} / \mathrm{mL}$ ), Peroxiredoxin-1 (PRDX1, Affinity, dilution 1:2000), Band 3 anion transport protein (SLC4A1, Affinity, dilution 1:2000), Transferrin (Affinity, dilution 1:2000) at $4{ }^{\circ} \mathrm{C}$ over-night. And subsequently followed by incubated with horseradish peroxidase-conjugated secondary antibodies for $2 \mathrm{~h}$ at room temperature. Transferrin was detected as an internal reference protein [12]. Protein bands were visualized by enhanced chemiluminescence reagents and the protein intensity was quantified using Image-J software. Data was expressed as mean \pm standard deviation, group comparisons were processed using the two-tailed Student's $t$-test, $p<0.05$ was considered as statistical significance.

\section{Results}

\section{Clinical characteristics and biochemical data of the study subjects}

The clinical characteristics and biochemical data of the study subjects were collected and analyzed, and the relative results were presented in Table 1 . In this study, the study subjects included 31 healthy women as controls and 31 PCOS women. There are no statistically differences for the age and BMI between the two groups ( $p$ value $>0.05$ ). For PCOS related biochemical data, the levels of fasting glucose, LH, T, TG, LDL-c and LH/FSH ratio were significantly higher in PCOS patients than those in the controls, the levels of PRL, HDL-c were significantly lower in PCOS patients than those in the controls $(p$ value $<0.05)$.

\section{Quality control of the proteomics analysis}

The intensity of all identified proteins showed that the abundance of these proteins spans largely, covering 5
Table 1 Clinical characteristic of the study subjects

\begin{tabular}{lccl}
\hline & Control $(\mathbf{n}=\mathbf{3 1})$ & PCOS $(\mathbf{n}=\mathbf{3 1})$ & $\boldsymbol{p}$ value \\
\hline Age [years] & $24.52 \pm 2.31$ & $24.20 \pm 4.49$ & 0.750 \\
BMI [kg/m $\left.{ }^{2}\right]$ & $20.48 \pm 2.67$ & $22.27 \pm 3.56$ & 0.081 \\
Fasting glucose & $4.68 \pm 0.42$ & $5.25 \pm 1.20$ & $0.026<0.05$ \\
$\quad[\mathrm{mmol} / \mathrm{L}]$ & & & \\
FSH $[\mathrm{IU} / \mathrm{L}]$ & $5.15 \pm 1.32$ & $5.59 \pm 2.86$ & 0.440 \\
LH [IU/L] & $5.85 \pm 2.74$ & $9.82 \pm 8.57$ & $0.017<0.05$ \\
LH/FSH & $1.14 \pm 0.50$ & $1.73 \pm 0.97$ & $0.003<0.01$ \\
PRL [m/U/L] & $466.83 \pm 231.05$ & $309.64 \pm 158.59$ & $0.003<0.01$ \\
E2 [pmol/L] & $209.95 \pm 127.20$ & $220.25 \pm 246.80$ & 0.837 \\
T [nmol/L] & $1.12 \pm 0.40$ & $1.65 \pm 0.67$ & $<0.001$ \\
P [nmol/L] & $0.93 \pm 0.36$ & $1.05 \pm 0.80$ & 0.451 \\
TC [mmol/L] & $4.44 \pm 0.63$ & $4.65 \pm 0.76$ & 0.306 \\
TG $[\mathrm{mmol} / \mathrm{L}]$ & $0.75 \pm 0.29$ & $1.13 \pm 0.51$ & $0.002<0.05$ \\
HDL-c [mmol/L] & $2.23 \pm 0.52$ & $1.46 \pm 0.41$ & $<0.001$ \\
LDL-c [mmol/L] & $1.69 \pm 0.29$ & $2.54 \pm 0.62$ & $<0.001$ \\
\hline
\end{tabular}

orders of magnitude, suggesting that the instrument is more sensitive (Fig. 1a). Coefficient of variation $(\mathrm{CV})$ of the control group and PCOS group samples were 37.7\% and $32.9 \%$, respectively. Pearson correlation analysis of the protein intensity showed that the correlation index was among 0.8-1, suggested that the experimental procedures are reproducible (Fig. 1b, c). Blood coagulation is a interference factor for serum proteomics analysis, the decrease of fibrinogen indicates the coagulation event. We detected the serum levels of fibrinogen alpha chain (FGA), fibrinogen beta chain (FGB), fibrinogen gamma chain (FGG), the results showed that there are no significant decreases of FGA, FGB and FGG in all samples, suggested there is no coagulation event in our tested samples (Fig. 1d).

\section{Principal component analysis (PCA)}

There were 550 proteins were identified and filtered from the dataset. The PCA and OPLS-DA were performed based on the quantitative data of these proteins to determine the principal axes on protein abundance variations in PCOS cases and controls. The PCA (Fig. 2a) showed moderate separation of the serum proteins between the PCOS and control group at $t(2)$ axis, but with overlaps at $t(1)$ axis. Further OPLS-DA result (Fig. 2b, c) showed complete separation of the serum proteins between the PCOS and control group. The quality parameters of the model were: $\mathrm{R}^{2} \mathrm{Y}=0.94 ; \mathrm{Q}^{2}=0.71$. The OPLS-DA model was also verified by 999 times permutation test (Fig. 2d).

\section{Proteomics in PCOS patients and controls}

A total of 80 proteins were significantly differentially abundant in PCOS patients compared to the healthy 


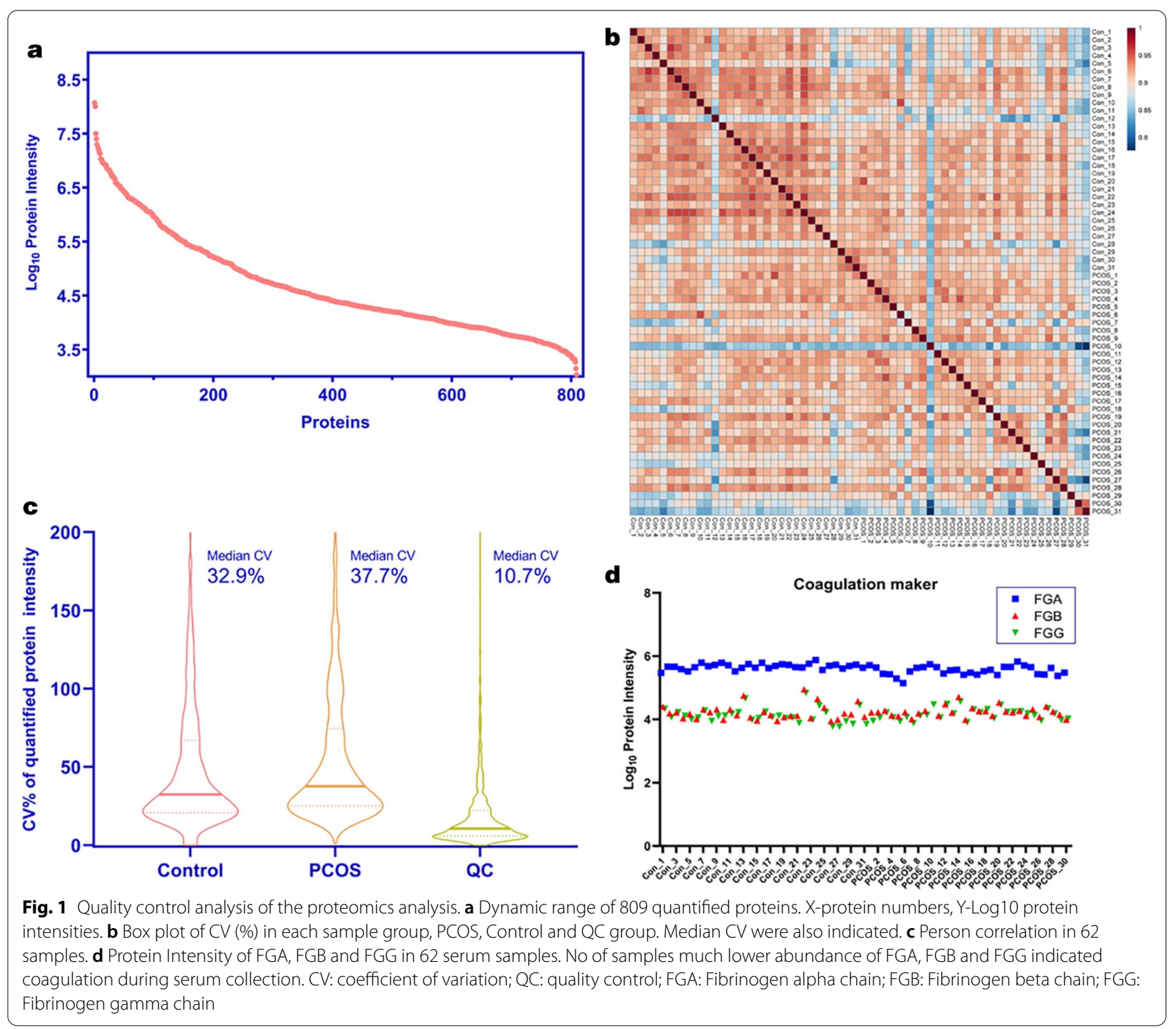

controls from the criterion $p$ value after BenjaminHocheberg FDR adjustment $\mathrm{p}$ value was less than 0.05 . The detailed information of these proteins were presented in Table 2. Among these proteins, 56 were downregulated, 24 were up-regulated (Fig. 3a). Heatmap (Fig. 3b) also showed the expression intensity of these proteins, and these proteins were clustered significantly in the samples between the PCOS and control groups.

\section{Bioinformatics analysis of the proteomic results}

The GO terms of these 56 down-regulated and 24 upregulated proteins enriched were shown in Fig. 4. GO terms were divided into three categories, biological process (BP), cellular component (CC), and molecular function (MF). GO analysis of the downregulated proteins showed that the enriched BP terms include response to stimulus, biological regulation, metabolic process, cell proliferation, and especially reproduction term. The GO terms that upregulated proteins enriched were similar to those downregulated proteins. Volcano plot (Fig. 5) of GO and KEGG enrichment results showed that 54 downregulated proteins were enriched in terms including platelet degranulation, cell adhesion, biological adhesion, cell activation, regulated exocytosis, blood coagulation, coagulation, hemostasis, defense response and inflammatory response. 26 upregulated proteins were enriched in terms including viral carcinogenesis, alcoholism, systemic lupus erythematosus, cofactor catabolic process, hydrogen peroxide catabolic process, antioxidant activity, cellular oxidant 


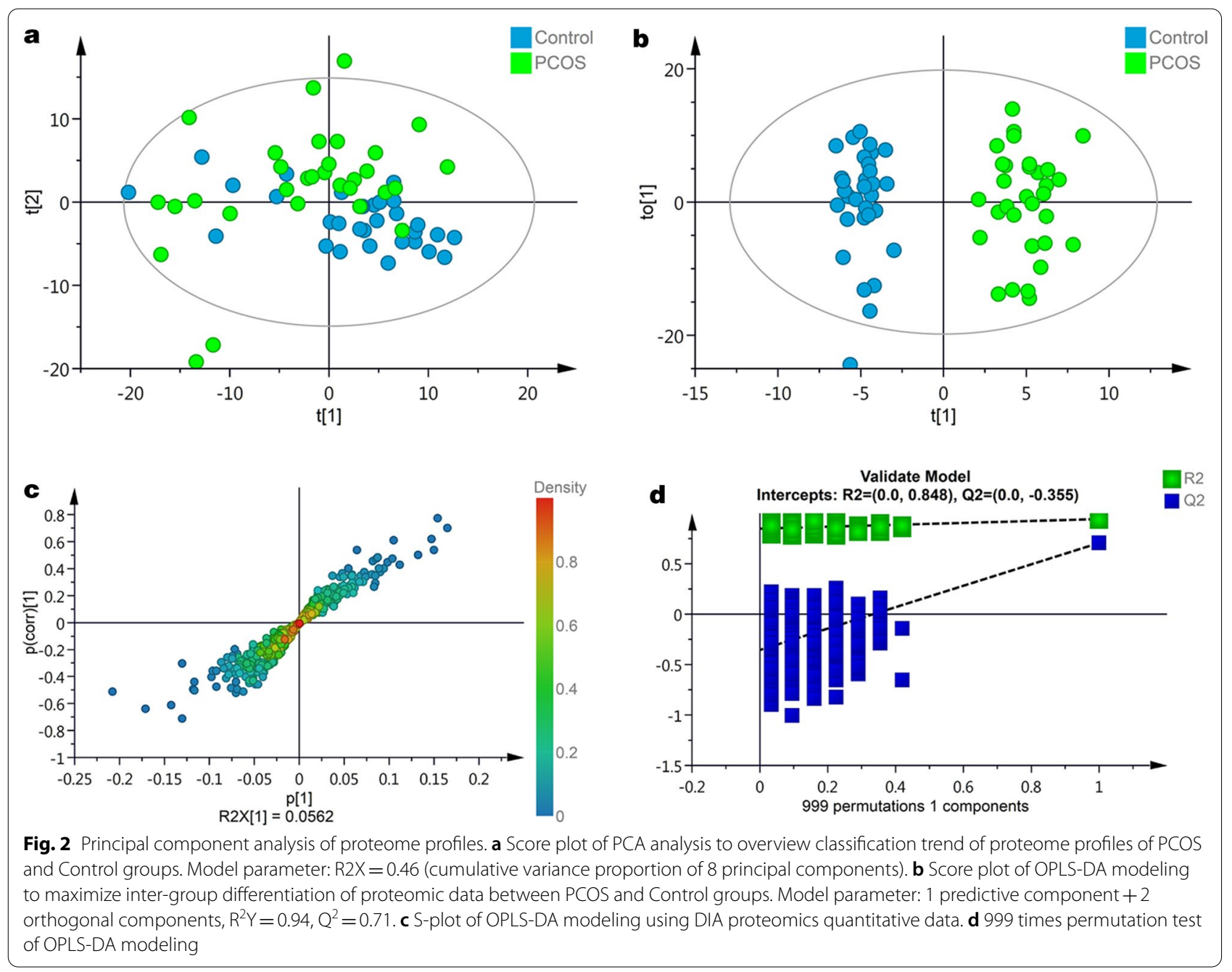

detoxification, cellular detoxification, antibiotic catabolic process and hydrogen peroxide metabolic process.

\section{ROC curves analysis}

In order to explore the diagnoses potential of these 80 proteins in PCOS cases, all the 80 proteins were further introduced for ROC curves analysis. And top 10 proteins with the higher area under curve (AUC) were presented in Fig. 6 and Table 3, including H4, H2A, TLT-1, PRDX1, SLC4A1, Protein NYNRIN (NYNRIN), Zyxin (ZYX), Transgelin-2 (TAGLN2), Contactin-1 (CNTN1), Histone $\mathrm{H} 2 \mathrm{~B}$ (H2B). It could be observed that the AUC of $\mathrm{H} 4, \mathrm{H} 2 \mathrm{~A}$, TLT-1 were all over than $0.9(\mathrm{AUC}=0.966$, $0.940,0.912$, respectively), and they were all differentially abundant in PCOS and control subjects significantly, indicated promising diagnosis values of these proteins.

\section{Validation the expression of significant proteins}

Based on the former DIA proteomics results and the identified significant biomarkers, we chose the expression of top five significant proteins (H4, H2A, TLT-1, PRDX1, SLC4A1) from the ROC curves results for further validation using Western blot analysis. As shown in Fig. 7, the expression of H4, H2A, PRDX1, SLC4A1 in PCOS group were significantly increased comparing to the control group, but the expression of TLT-1 was significantly decreased in PCOS group comparing to the control group. More importantly, tendency of these detected proteins between the PCOS and control groups were consisted with the DIA proteomics results.

\section{Discussion}

Despite the great potential of -omic sciences in elucidating biological processes and monitoring disease progression, comprehensive proteomic analysis on PCOS patients has not been investigate fully to date $[8,13]$. In 
Table 2 List of the 80 differential expressed proteins in PCOS patients plasma

\begin{tabular}{|c|c|c|c|c|c|c|}
\hline No & Protein accessions & Proteins & Proteins & $\begin{array}{l}\text { FDR adj } p \\
\text { value PCOS } \\
\text { Con }\end{array}$ & PCOS/Con ratio & $\begin{array}{l}-\log 10 \text { (FDR adj } p \\
\text { value PCOS/Con) }\end{array}$ \\
\hline 1 & O60814 & $\mathrm{H} 2 \mathrm{~B}$ & Histone $\mathrm{H} 2 \mathrm{~B}$ & 1.87E-03 & 3.852 & 2.729 \\
\hline 2 & P04908 & $\mathrm{H} 2 \mathrm{~A}$ & Histone $\mathrm{H} 2 \mathrm{~A}$ & $3.29 \mathrm{E}-07$ & 3.658 & 6.482 \\
\hline 3 & P11277 & SPTB & Spectrin beta chain, erythrocytic & $1.13 \mathrm{E}-03$ & 3.475 & 2.945 \\
\hline 4 & P02730 & SLC4A1 & Band 3 anion transport protein & $2.70 \mathrm{E}-05$ & 3.279 & 4.569 \\
\hline 5 & P62805 & $\mathrm{H} 4$ & Histone H4 & 4.47E-09 & 2.784 & 8.350 \\
\hline 6 & P05388 & RPLPO & 605 acidic ribosomal protein P0 & $1.30 \mathrm{E}-02$ & 2.660 & 1.886 \\
\hline 7 & O75460 & ERN1 & $\begin{array}{l}\text { Serine/threonine-protein kinase/endoribonuclease } \\
\text { IRE1 }\end{array}$ & $1.66 \mathrm{E}-02$ & 2.201 & 1.781 \\
\hline 8 & P30041 & PRDX6 & Peroxiredoxin-6 & $6.48 \mathrm{E}-03$ & 2.160 & 2.189 \\
\hline 9 & B9A064 & IGLL5 & Immunoglobulin lambda-like polypeptide 5 & $3.17 \mathrm{E}-02$ & 2.154 & 1.498 \\
\hline 10 & P04040 & CAT & Catalase & $2.76 \mathrm{E}-02$ & 1.934 & 1.559 \\
\hline 11 & P00738 & $\mathrm{HP}$ & Haptoglobin & 4.10E-02 & 1.926 & 1.387 \\
\hline 12 & P13716 & ALAD & Delta-aminolevulinic acid dehydratase & $2.41 \mathrm{E}-02$ & 1.903 & 1.618 \\
\hline 13 & Q9P2P1 & NYNRIN & Protein NYNRIN & $3.62 \mathrm{E}-02$ & 1.875 & 1.441 \\
\hline 14 & P01857 & $\mid \mathrm{GHG} 1$ & Ig gamma- 1 chain $C$ region & $4.16 \mathrm{E}-02$ & 1.835 & 1.380 \\
\hline 15 & Q06830 & PRDX1 & Peroxiredoxin-1 & $5.92 \mathrm{E}-05$ & 1.832 & 4.228 \\
\hline 16 & P32119 & PRDX2 & Peroxiredoxin-2 & $9.11 \mathrm{E}-03$ & 1.629 & 2.040 \\
\hline 17 & P05062 & ALDOB & Fructose-bisphosphate aldolase B & $3.85 \mathrm{E}-02$ & 1.614 & 1.415 \\
\hline 18 & P30043 & BLVRB & Flavin reductase (NADPH) & $1.48 \mathrm{E}-02$ & 1.612 & 1.830 \\
\hline 19 & P00918 & CA2 & Carbonic anhydrase 2 & $1.66 \mathrm{E}-02$ & 1.563 & 1.781 \\
\hline 20 & Q15293 & RCN1 & Reticulocalbin-1 & $3.62 \mathrm{E}-02$ & 1.450 & 1.441 \\
\hline 21 & P00558 & PGK1 & Phosphoglycerate kinase 1 & $4.75 E-02$ & 1.376 & 1.323 \\
\hline 22 & P02751 & FN1 & Fibronectin & $1.25 \mathrm{E}-03$ & 1.298 & 2.904 \\
\hline 23 & Q92954 & PRG4 & Proteoglycan 4 & 4.37E-02 & 1.289 & 1.359 \\
\hline 24 & P78417 & GSTO1 & Glutathione S-transferase omega-1 & $3.04 \mathrm{E}-02$ & 1.276 & 1.517 \\
\hline 25 & P04275 & VWF & von Willebrand factor & $2.76 \mathrm{E}-02$ & 1.275 & 1.559 \\
\hline 26 & Q9H3P2 & NELFA & Negative elongation factor A & $3.45 \mathrm{E}-02$ & 1.160 & 1.462 \\
\hline 27 & Q6UX71 & PLXDC2 & Plexin domain-containing protein 2 & $2.94 \mathrm{E}-02$ & 0.876 & 1.531 \\
\hline 28 & P08195 & SLC3A2 & 4F2 cell-surface antigen heavy chain & $4.39 E-02$ & 0.872 & 1.357 \\
\hline 29 & P51884 & LUM & Lumican & $4.10 \mathrm{E}-02$ & 0.866 & 1.388 \\
\hline 30 & O75882 & ATRN & Attractin & $4.08 \mathrm{E}-02$ & 0.864 & 1.390 \\
\hline 31 & P20851 & C4BPB & C4b-binding protein beta chain & 4.66E-02 & 0.857 & 1.331 \\
\hline 32 & P00734 & $F 2$ & Prothrombin & $4.45 E-03$ & 0.852 & 2.351 \\
\hline 33 & P14151 & SELL & L-selectin & $2.59 E-02$ & 0.851 & 1.586 \\
\hline 34 & P06396 & GSN & Gelsolin & 4.16E-02 & 0.844 & 1.380 \\
\hline 35 & O00533 & $\mathrm{CHL} 1$ & Neural cell adhesion molecule L1-like protein & 1.15E-02 & 0.838 & 1.938 \\
\hline 36 & P55058 & PLTP & Phospholipid transfer protein & $2.88 \mathrm{E}-02$ & 0.824 & 1.541 \\
\hline 37 & P07359 & GP1BA & Platelet glycoprotein Ib alpha chain & $1.89 E-02$ & 0.819 & 1.723 \\
\hline 38 & P08253 & MMP2 & $72 \mathrm{kDa}$ type IV collagenase & $2.59 \mathrm{E}-02$ & 0.816 & 1.586 \\
\hline 39 & Q14126 & DSG2 & Desmoglein-2 & $1.87 \mathrm{E}-02$ & 0.814 & 1.728 \\
\hline 40 & Q9NPH3 & IL1RAP & Interleukin-1 receptor accessory protein & $8.88 \mathrm{E}-03$ & 0.811 & 2.051 \\
\hline 41 & P07998 & RNASE1 & Ribonuclease pancreatic & $2.59 \mathrm{E}-02$ & 0.811 & 1.586 \\
\hline 42 & P02776 & PF4 & Platelet factor 4 & $2.70 \mathrm{E}-02$ & 0.806 & 1.569 \\
\hline 43 & P07996 & THBS1 & Thrombospondin-1 & $2.59 \mathrm{E}-02$ & 0.797 & 1.586 \\
\hline 44 & Q07954 & LRP1 & Prolow-density lipoprotein receptor-related protein 1 & $3.81 \mathrm{E}-02$ & 0.793 & 1.419 \\
\hline 45 & Q15166 & PON3 & Serum paraoxonase/lactonase 3 & $1.66 \mathrm{E}-02$ & 0.790 & 1.781 \\
\hline 46 & P05452 & CLEC3B & Tetranectin & $9.11 \mathrm{E}-03$ & 0.789 & 2.040 \\
\hline 47 & P10643 & $\mathrm{C7}$ & Complement component C7 & $8.88 \mathrm{E}-03$ & 0.788 & 2.051 \\
\hline
\end{tabular}


Table 2 (continued)

\begin{tabular}{|c|c|c|c|c|c|c|}
\hline No & Protein accessions & Proteins & Proteins & $\begin{array}{l}\text { FDR adj } p \\
\text { value PCOS } \\
\text { Con }\end{array}$ & PCOS/Con ratio & $\begin{array}{l}-\log 10 \text { (FDR adj } p \\
\text { value PCOS/Con) }\end{array}$ \\
\hline 48 & P54289 & CACNA2D1 & $\begin{array}{l}\text { Voltage-dependent calcium channel subunit } \\
\text { alpha-2/delta-1 }\end{array}$ & $3.49 \mathrm{E}-02$ & 0.780 & 1.457 \\
\hline 49 & P05067 & APP & Amyloid beta A4 protein & $2.70 \mathrm{E}-02$ & 0.764 & 1.569 \\
\hline 50 & Q12860 & CNTN1 & Contactin-1 & $1.25 \mathrm{E}-03$ & 0.762 & 2.904 \\
\hline 51 & Q99784 & OLFM1 & Noelin & $3.71 \mathrm{E}-02$ & 0.758 & 1.431 \\
\hline 52 & P40189 & IL6ST & Interleukin-6 receptor subunit beta & 3.17E-02 & 0.756 & 1.498 \\
\hline 53 & P02671 & FGA & Fibrinogen alpha chain & $1.25 \mathrm{E}-03$ & 0.723 & 2.904 \\
\hline 54 & P40197 & GP5 & Platelet glycoprotein V & $2.65 \mathrm{E}-03$ & 0.720 & 2.576 \\
\hline 55 & Q9BZE9 & ASPSCR1 & Tether containing UBX domain for GLUT4 & 4.13E-02 & 0.720 & 1.384 \\
\hline 56 & Q10588 & BST1 & ADP-ribosyl cyclase/cyclic ADP-ribose hydrolase 2 & $3.71 \mathrm{E}-02$ & 0.688 & 1.431 \\
\hline 57 & P13473 & LAMP2 & Lysosome-associated membrane glycoprotein 2 & 4.49E-02 & 0.682 & 1.348 \\
\hline 58 & P04066 & FUCA1 & Tissue alpha-L-fucosidase & 4.37E-02 & 0.680 & 1.359 \\
\hline 59 & Q8IVU3 & HERC6 & Probable E3 ubiquitin-protein ligase HERC6 & 3.17E-02 & 0.668 & 1.498 \\
\hline 60 & P02786 & TFRC & Transferrin receptor protein 1 & $2.66 \mathrm{E}-03$ & 0.667 & 2.575 \\
\hline 61 & P25311 & AZGP1 & Zinc-alpha-2-glycoprotein & $1.66 \mathrm{E}-02$ & 0.656 & 1.781 \\
\hline 62 & Q8WZ42 & TTN & Titin & 4.10E-03 & 0.653 & 2.388 \\
\hline 63 & P01009 & SERPINA1 & Alpha-1-antitrypsin & $2.70 E-02$ & 0.645 & 1.569 \\
\hline 64 & P05090 & APOD & Apolipoprotein D & 3.17E-02 & 0.629 & 1.498 \\
\hline 65 & P16109 & SELP & P-selectin & $3.88 \mathrm{E}-02$ & 0.618 & 1.412 \\
\hline 66 & Q15848 & ADIPOQ & Adiponectin & $4.16 \mathrm{E}-02$ & 0.607 & 1.380 \\
\hline 67 & P04745 & AMY1A & Alpha-amylase 1 & $2.70 \mathrm{E}-02$ & 0.582 & 1.569 \\
\hline 68 & Q16853 & $\mathrm{AOC} 3$ & Membrane primary amine oxidase & $2.45 \mathrm{E}-02$ & 0.575 & 1.611 \\
\hline 69 & P54108 & CRISP3 & Cysteine-rich secretory protein 3 & $2.11 \mathrm{E}-02$ & 0.573 & 1.676 \\
\hline 70 & P58335 & ANTXR2 & Anthrax toxin receptor 2 & $3.17 \mathrm{E}-02$ & 0.565 & 1.498 \\
\hline 71 & Q5VY43 & PEAR1 & Platelet endothelial aggregation receptor 1 & $2.13 \mathrm{E}-02$ & 0.563 & 1.671 \\
\hline 72 & P18065 & IGFBP2 & Insulin-like growth factor-binding protein 2 & 5.87E-03 & 0.551 & 2.231 \\
\hline 73 & PODMV8 & HSPA1A & Heat shock $70 \mathrm{kDa}$ protein $1 \mathrm{~A}$ & $2.70 \mathrm{E}-02$ & 0.455 & 1.569 \\
\hline 74 & Q86YW5 & TLT-1 & Trem-like transcript 1 protein & $3.11 \mathrm{E}-07$ & 0.452 & 6.507 \\
\hline 75 & P21926 & CD9 & CD9 antigen & $3.64 \mathrm{E}-03$ & 0.411 & 2.438 \\
\hline 76 & P08567 & PLEK & Pleckstrin & $4.45 \mathrm{E}-03$ & 0.392 & 2.351 \\
\hline 77 & P37802 & TAGLN2 & Transgelin-2 & 2.37E-04 & 0.352 & 3.626 \\
\hline 78 & 015394 & NCAM2 & Neural cell adhesion molecule 2 & $1.10 \mathrm{E}-02$ & 0.350 & 1.957 \\
\hline 79 & Q15942 & $Z Y X$ & Zyxin & $3.91 \mathrm{E}-05$ & 0.219 & 4.408 \\
\hline 80 & Q8IVT5 & KSR1 & Kinase suppressor of Ras 1 & $2.04 \mathrm{E}-03$ & 0.060 & 2.691 \\
\hline
\end{tabular}

this study, by quantitative DIA proteomics, we aimed to investigate whether proteomics change in PCOS women serum samples compared to the healthy controls, and the results evidenced the serum proteomic profile alterations in PCOS female. As a result, there were 80 proteins significantly differentially expressed between PCOS patients and controls, including 54 downregulated and 26 upregulated proteins. GO and KEGG analysis showed that downregulated proteins were enriched in platelet degranulation, cell adhesion, cell activation, blood coagulation, hemostasis, defense response and inflammatory response terms; upregulated proteins were enriched in cofactor catabolic process, hydrogen peroxide catabolic process, antioxidant activity, cellular oxidant detoxification, cellular detoxification, antibiotic catabolic process and hydrogen peroxide metabolic process. ROC curves analysis showed that the AUC of $\mathrm{H} 4, \mathrm{H} 2 \mathrm{~A}$, TLT-1 were all over than 0.9 , indicated promising diagnosis values of these proteins.

Serum proteomics results showed that there were 80 proteins differentially expressed between PCOS patients and controls significantly. Further GO and KEGG enrichment analysis indicated that the downregulated proteins were enriched in platelet degranulation, blood 


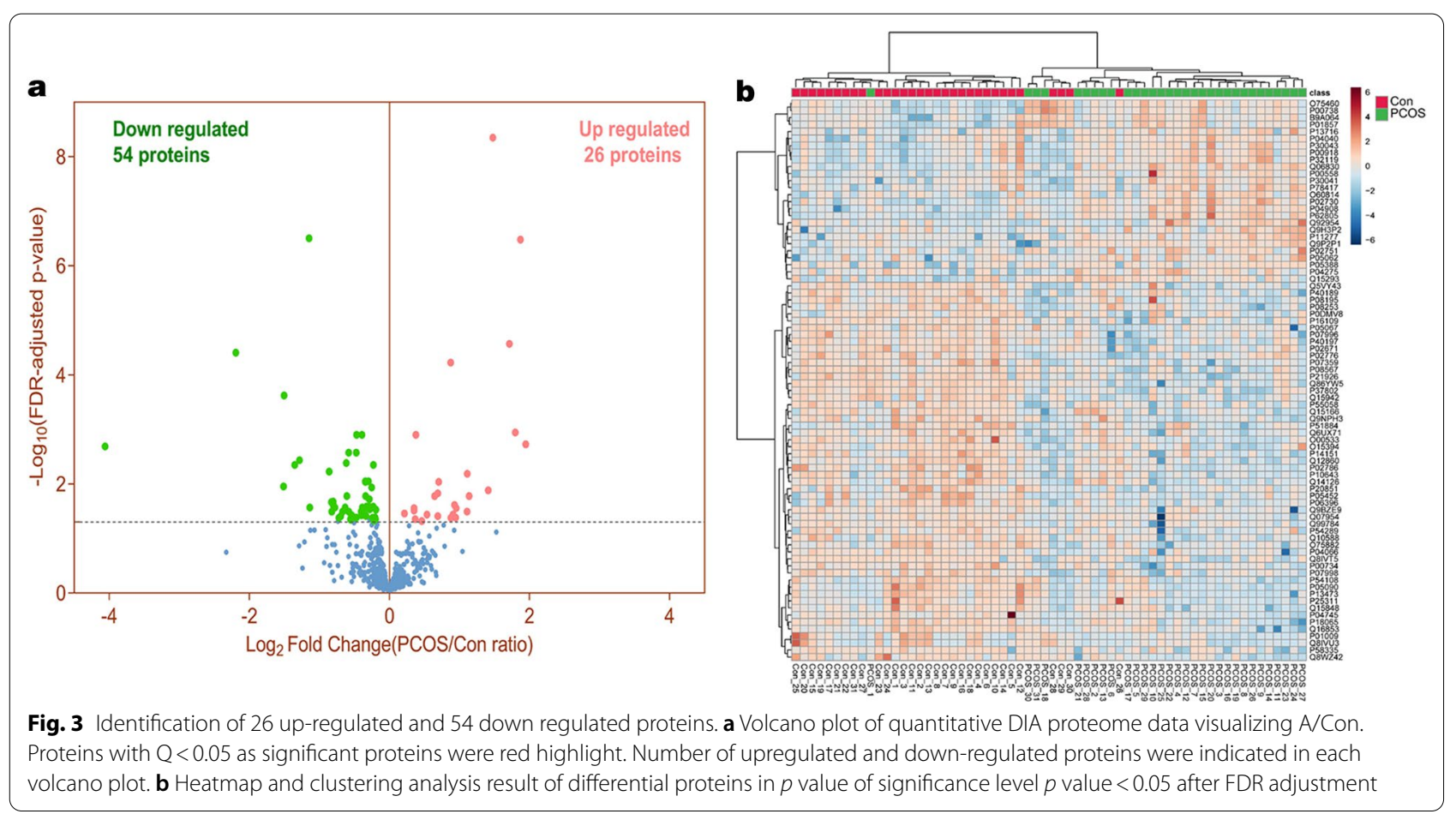

coagulation and inflammatory response. Reproductive disorders, such as PCOS, are often accompanied by platelet dysfunctions and thereby induced inflammation [14]. In patients with PCOS, coagulation and fibrinolysis parameters are usually evaluated. Platelet involves in granulosa cell corpus luteum formation and angiogenesis in ovary, and abnormal follicular development in PCOS is partly contributed by ovarian angiogenesis dysregulation. Aye et al. examined the effect of hypertriglyceridemia on IR and platelet function in young women with PCOS, and reported that acute hypertriglyceridemia induced IR, increased platelet activation both in control and PCOS groups [15]. PCOS patients also have risk to induce prothrombotic state, and platelet dysfunction might responsible for it. This study showed that changed proteins were enriched in platelet degranulation and blood coagulation in PCOS group, which indicated that these protein changes might contributed to the platelet dysfunction, and also associated with IR and inflammation. GO results also showed that these changed proteins were also enriched in reproduction biological process, which indicated that the proteomics changes in PCOS cases were directly associated with the PCOS pathogenesis and induced infertility. In addition, PCOS is also a low-grade chronic inflammation disease, continuous releasing of inflammatory mediators could perpetuate the inflammatory condition in women with PCOS $[16,17]$. Proteomics changes can also impact on inflammatory response and reveal the presence of inflammation in disease [18]. For the identified proteins that enriched in inflammatory response in this analysis, some proteins were related to blood coagulation, including thrombin (also called coagulation factor II), platelet factor 4, thrombospondin 1 . Some publications also reported the associations of them with inflammation of PCOS [19-21]. Platelets are inflammatory anuclear cells, blood coagulation is an intrinsic pathway for proinflammation, blood coagulation factors also are important inflammatory mediators than just promoting or inhibiting blood coagulation [22-24]. The activation of coagulation factors could cause a proinflammatory response and initiate coagulation and downstream cellular signaling pathways.

Our ROC curves results showed that the AUC of H4, H2A, TLT-1 were all over than 0.9 , indicated a significant role of these three proteins in differentiating PCOS from controls. Among these three proteins, proteomics analysis showed that $\mathrm{H} 4$ and $\mathrm{H} 2 \mathrm{~A}$ was upregulated in PCOD patients with a PCOS/control ratio of 2.79 and 3.66, respectively. Histone is one of the critical components of chromatin, the amino acid residues at its N-terminus can be covalently modified, thus change the chromatin conformation and induce transcription or gene silencing [25]. This modification mainly including acetylation/deacetylation, methylation/demethylation, ubiquitination/deubiquitination, phosphorylation, sumo, biotin, etc. Excepting for gene expression controlling, 

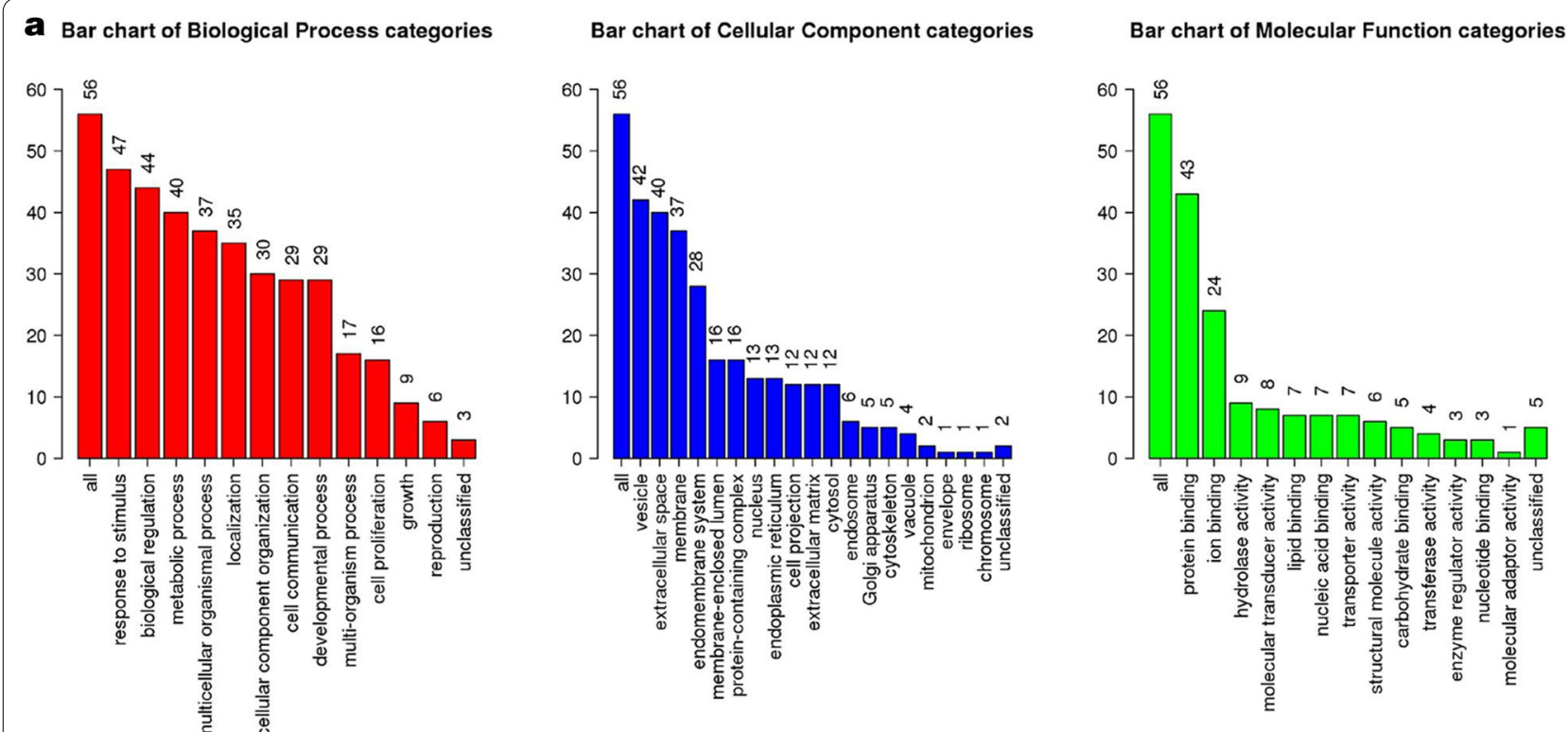

b Bar chart of Biological Process categories

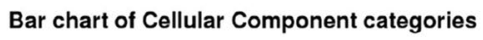

Bar chart of Molecular Function categories
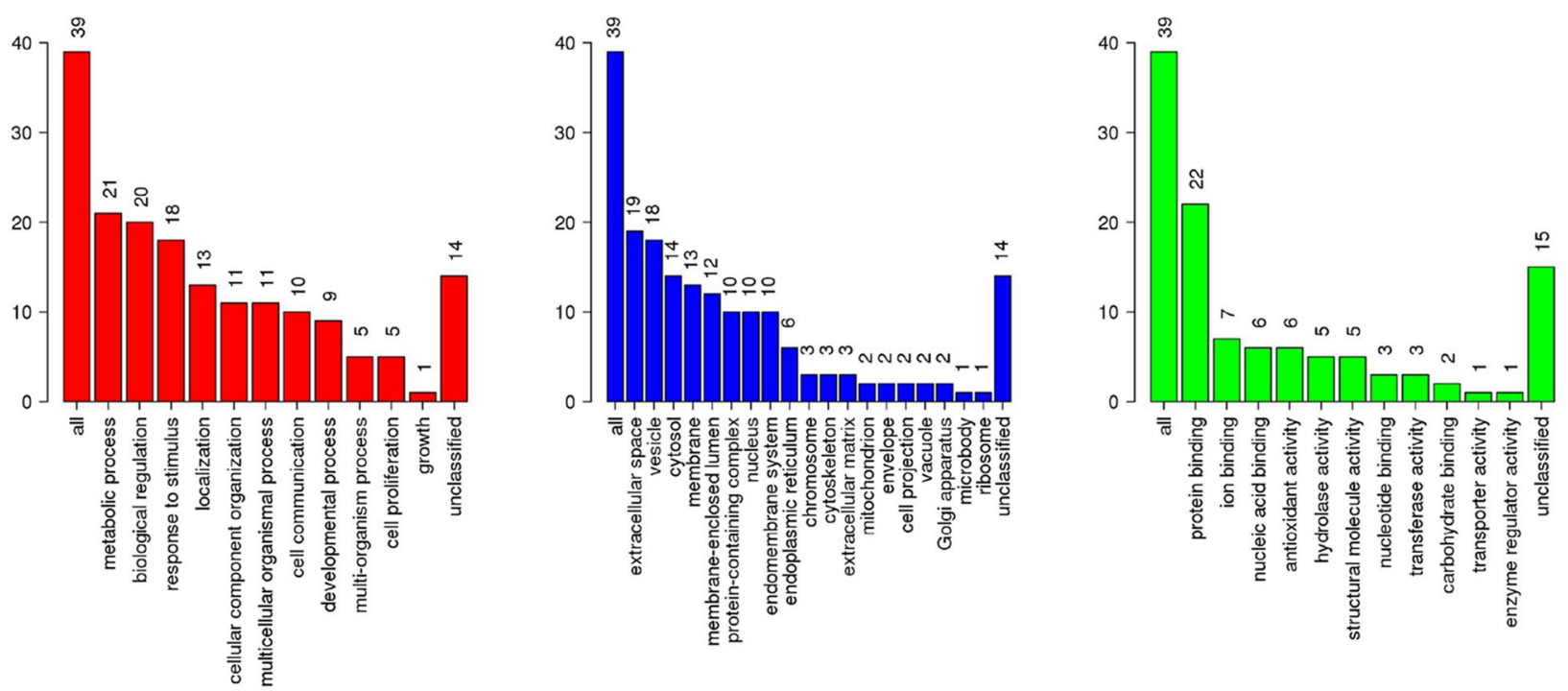

Fig. 4 Volcano plot of GO (GOBP, GOCC and GOMF) and KEGG enrichment result using over-representation method. Left: 54 DOWN-regulated proteins in PCOS group compared to sample Control group; Right: 26 Up-regulated proteins in PCOS group compared to Control group. Those genesets with FDR adjusted $p$ value $<0.05$ were labeled

histone modification also participates in cell division, cell apoptosis and memory formation by recruiting protein complex and affecting downstream proteins, and also has the impact on immune system and inflammatory reaction [26]. Histone subunits include H2A, H2B, $\mathrm{H} 3$ and $\mathrm{H} 4$, the histone modifications aforementioned could all be occurred and thus exhibit multiple functions. But previous studies about $\mathrm{H} 4$ or $\mathrm{H} 2 \mathrm{~A}$ in PCOS is rare. Monteiro's study reported that in endometriosis patients, lesions had significantly lower levels of Histone H3K9ac and Histone H4K16 acetylation compared to eutopic endometrium from controls, and comparing to the control endometrium, the hypoacetylation of Histone H3/ $\mathrm{H} 4$ within promoter regions of candidate genes known to be downregulated in endometriosis lesions, while the stereoidogenic factor 1 promoter region was enriched for acetylated $\mathrm{H} 3$ and $\mathrm{H} 4$ in lesions versus control tissues, correlating with its reported high expression in lesions [27]. Neonatal exposure to diethylstilbestrol (DES) can cause permanent alterations in female reproductive 


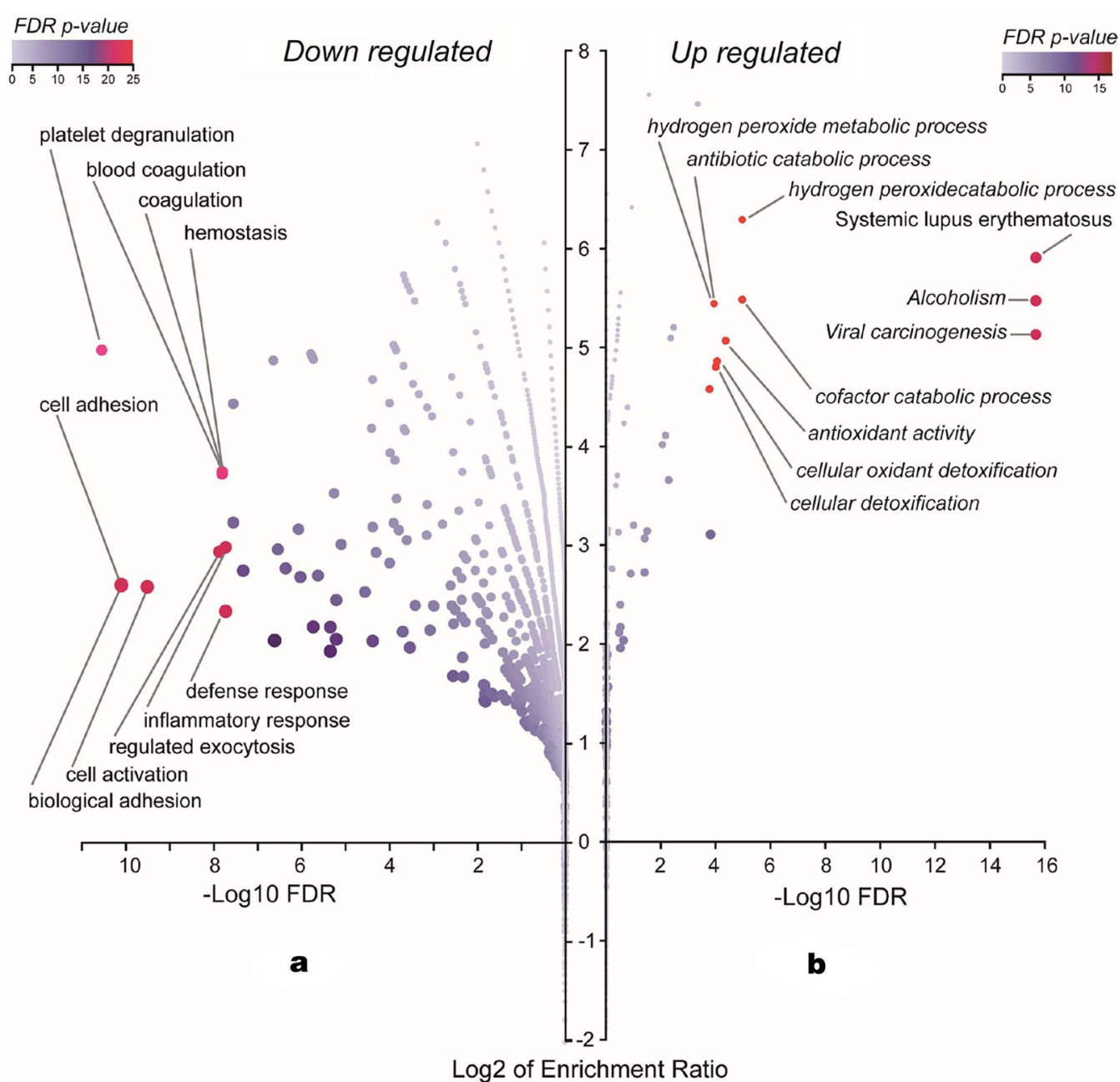

Fig. 5 Gene ontology analysis of the proteins. a GOBP, GOCC and GOMP enrichment results of 54 downregulated proteins. b GOBP, GOCC and GOMP enrichment results of 26 upregulated proteins. Y axis: protein numbers. GOBP: gene ontology biological process; GOCC: gene ontology cellular component; GOMP: gene ontology molecular function

tract gene expression, infertility, and uterine cancer in mice, after DES treatment, three histone modifications associated with active transcription, including Histone H4 lysine 5 acetylation (H4K5ac), which were found to enriched at specific lactoferrin (Ltf) promoter regions in uterine [28]. This suggested that the alteration expression of multiple chromatin-modifying proteins and epigenetic marks might lead to altered reproductive function and increased cancer risk.

TLT-1 is another protein with AUC over than 0.9 in ROC analysis. But different from the aforementioned two proteins, our proteomics analysis showed that TLT-1 was downregulated in PCOD patients with a PCOS/control ratio of 0.452 . TLT- 1 belongs to a kind of triggering receptors expressed on myeloid cells that play important roles in innate and adaptive immune responses, platelet aggregation, inflammation and insulted bleeding [29]. It mediates blood coagulation via binding fibrinogen. Based on the critical role in immune, inflammation and platelets, previous studies of TLT-1 are mainly focused on these associated diseases. In patients with systemic lupus erythematosus, the soluble TLT-1 levels were significantly lower than healthy individuals [30]. In a model of acute lung injury, results showed that infusion of sTLT-1 restored normal fibrinogen deposition and alleviated pulmonary hemorrhage by $40 \%$ and tissue damage by $25 \%$ [31]. In thrombocytopenia and platelet function defect, the content of TLT-1 was reduced, recombinant soluble TLT-1 could potentiate fibrinogen binding to patient platelets, and TLT-1 was found to be positively regulated by RUNX1 [32]. Derive et al. reported that TLT-1 is a potent endogenous regulator of sepsis-associated inflammation via suppressing leukocyte activation and modulating platelet-neutrophil crosstalk [33]. In this study, the 

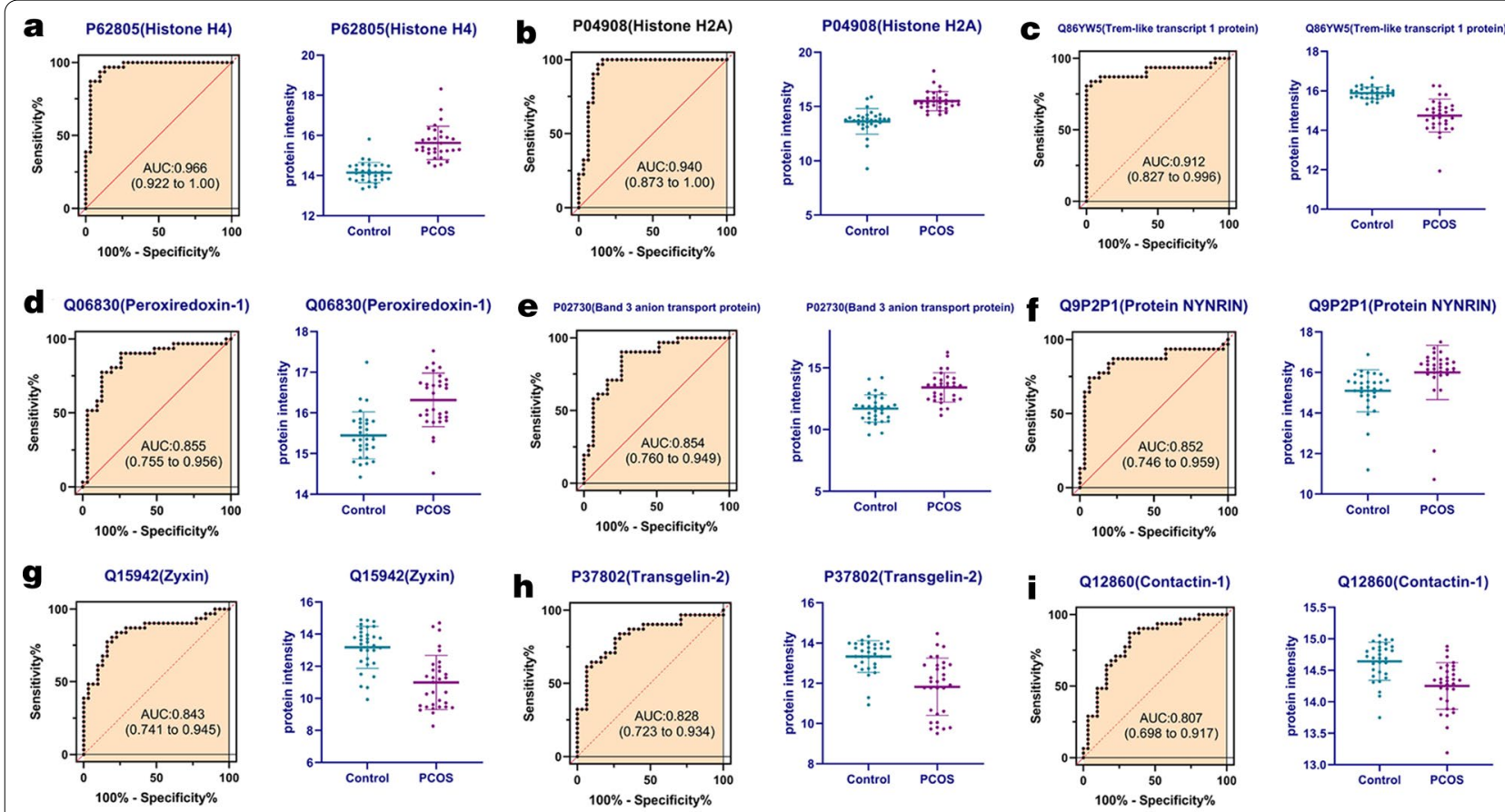

J 060814 (Histone H2B)
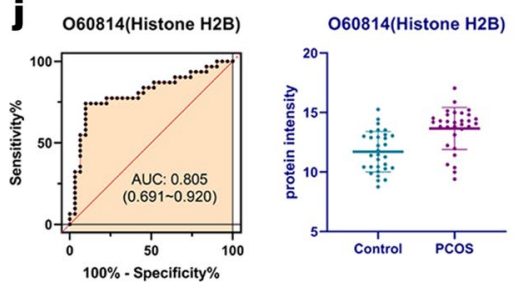

Fig. 6 ROC-curve analysis of top 10 proteins ranked AUC values

expression of TLT-1 was also downregulated, and AUC of ROC curves analysis was 0.912 . In this cases, we suspected that the changed expression of TLT-1 in PCOS

Table 3 Top 10 proteins ranked based on area under ROC curve

\begin{tabular}{|c|c|c|c|c|}
\hline Name & Protein & AUC & $\mathrm{FC}(\mathrm{PCOS} / \mathrm{Con})$ & $p$ value \\
\hline P62805 & Histone H4 & 0.966 & 2.79 & 4.47E-09 \\
\hline P04908 & Histone $\mathrm{H} 2 \mathrm{~A}$ & 0.940 & 3.66 & $3.29 E-07$ \\
\hline Q86YW5 & $\begin{array}{l}\text { Trem-like transcript } 1 \\
\text { protein }\end{array}$ & 0.912 & 0.45 & $3.11 \mathrm{E}-07$ \\
\hline Q06830 & Peroxiredoxin-1 & 0.855 & 1.83 & $5.92 \mathrm{E}-05$ \\
\hline P02730 & $\begin{array}{l}\text { Band } 3 \text { anion transport } \\
\text { protein }\end{array}$ & 0.854 & 3.27 & $2.70 E-05$ \\
\hline Q9P2P1 & Protein NYNRIN & 0.852 & 1.88 & $3.62 E-02$ \\
\hline Q15942 & Zyxin & 0.843 & 0.22 & $3.91 \mathrm{E}-05$ \\
\hline P37802 & Transgelin-2 & 0.828 & 0.35 & 2.37E-04 \\
\hline Q12860 & Contactin-1 & 0.807 & 0.76 & $1.25 \mathrm{E}-03$ \\
\hline O60814 & Histone $\mathrm{H}_{2} \mathrm{~B}$ & 0.805 & 3.86 & $1.87 \mathrm{E}-03$ \\
\hline
\end{tabular}

ROC, receiver operating characteristic; AUC, area under curve; $F C$, fold change might involved in the mediation of chronic inflammation and blood coagulation, thus impacting on the pathogenesis of PCOS.

In conclusion, this study enrolled 31 PCOS patients and 31 matched healthy control participators, by quantitative DIA proteomics analysis, we provided evidence of serum proteomic profile alterations in female with PCOS. 80 proteins were significantly differentially expressed between PCOS patients and controls, including 54 downregulated and 26 upregulated proteins. GO and KEGG analysis showed that downregulated proteins were enriched in platelet degranulation, cell adhesion, cell activation, blood coagulation, hemostasis, defense response and inflammatory response terms; upregulated proteins were enriched in cofactor catabolic process, hydrogen peroxide catabolic process, antioxidant activity, cellular oxidant detoxification, cellular detoxification, antibiotic catabolic process and hydrogen peroxide metabolic process. ROC curves analysis showed that the AUC of $\mathrm{H} 4$, H2A, TLT-1 were all over than 0.9 , indicated promising diagnosis values of these proteins in PCOS. Western 


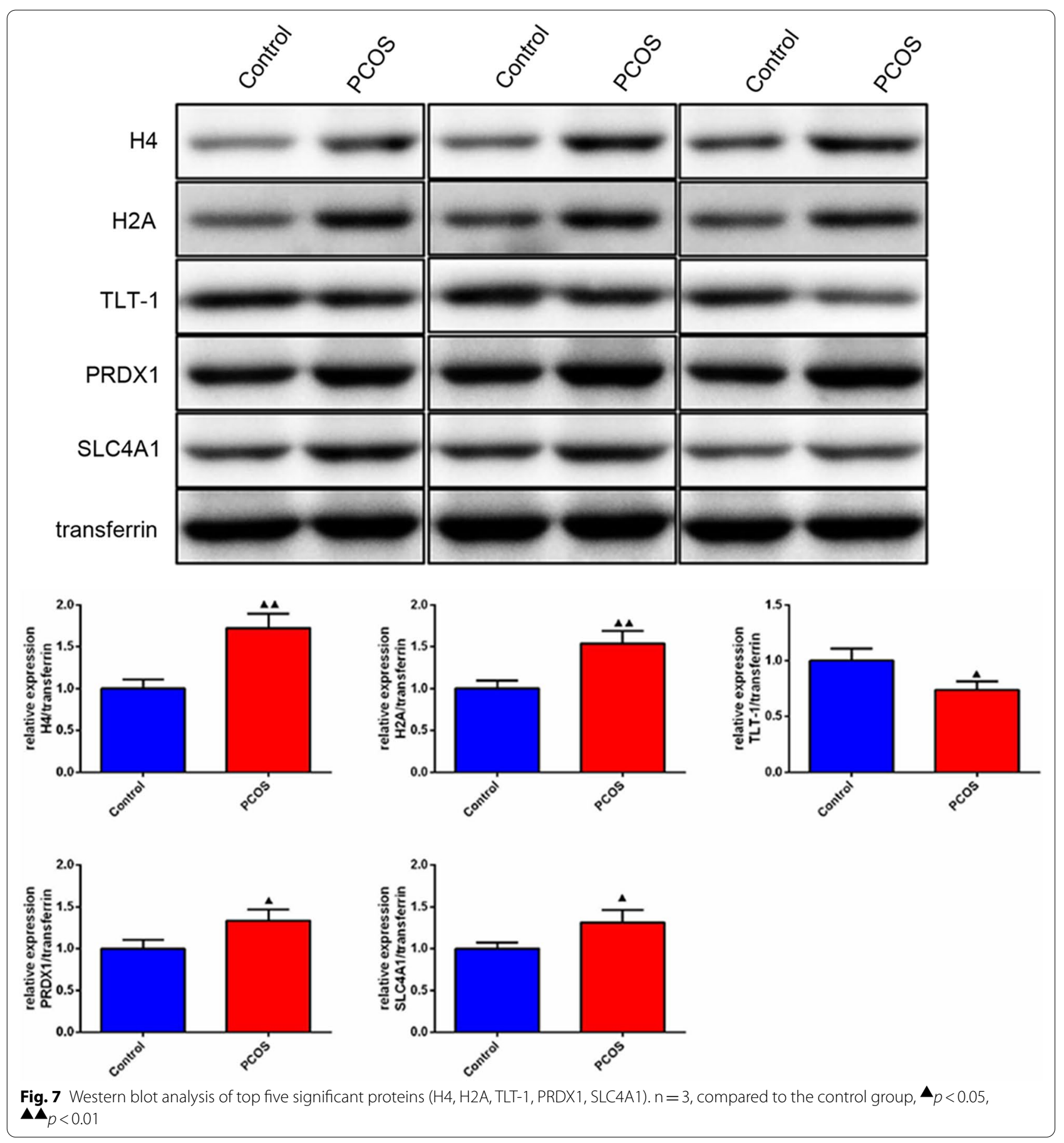

blotting also validated that H4, H2A, TLT-1, PRDX1, SLC4A1 were differently expressed in PCOS and control groups significantly. Future studies comparing systemic expression and exact role of these candidate biomarkers in PCOS are essential for confirmation of this hypothesis.

\section{Acknowledgement}

Not applicable.

\section{Authors' contributions}

Conception and design of the research: HXX, YY. Acquisition of data: PLT, RYQ Analysis and interpretation of data: ZCZ. Statistical analysis: ZJW. Drafting the manuscript: $H X X, Y Y, L C Z$. Revision of manuscript for important intellectual content: HXX, YY, ZJW. All authors read and approved the final manuscript. Ying Yu et al. the significant proteins as candidate biomarkers in women with PCOS

\section{Funding}

Not applicable. 


\section{Availability of data and materials}

The datasets supporting the conclusions of this article are included within the article.

\section{Declarations}

\section{Ethics approval and consent to participate}

This study received the ethical approval from the Ethics Committee of Zhejiang Provincial Hospital of Chinese Medicine. [2020-KL-155-02] and conforms to the principles outlined in the Declaration of Helsinki. All the participators signed informed consent forms before the start of the study. All protocols are carried out in accordance with relevant guidelines and regulations of "The Regulations of Ethical Reviews of Biomedical Research Involving Human Subjects".

\section{Consent for publication}

Written informed consent for publication was obtained from all participants.

\section{Patient consent for publication}

Not applicable.

\section{Competing interests}

The authors declare that they have no conflict of interest.

\section{Author details}

${ }^{1}$ Institute of Laboratory Medicine, Jiangsu Key Laboratory of Laboratory Medicine, Jiangsu University, No. 301 Xuefu Road, Zhenjiang, Jiangsu 210013, People's Republic of China. ${ }^{2}$ Department of Laboratory Medicine, Chinese Medicine Hospital of Zhejiang, Hangzhou, Zhejiang 310006, People's Republic of China.

Received: 13 January 2021 Accepted: 14 April 2021

Published online: 09 May 2021

\section{References}

1. Moghetti P, Tosi F. Insulin resistance and PCOS: chicken or egg? J Endocrinol Invest. 2021;44(2):233-44.

2. Goodman NF, Cobin RH, Futterweit W, Glueck JS, Legro RS, Carmina E, American Association of Clinical Endocrinologists (AACE); American College of Endocrinology (ACE); Androgen Excess and PCOS Society. American Association of Clinical Endocrinologists, American College Of Endocrinology, and Androgen Excess and PCOS Society Disease State Clinical Review: Guide to the Best Practices in the Evaluation and Treatment of Polycystic Ovary Syndrome-Part 2. Endocr Pract. 2015;21(12):1415-26.

3. Fearnley EJ, Marquart L, Spurdle AB, Weinstein P, Webb PM, Australian Ovarian Cancer Study Group and Australian National Endometrial Cancer Study Group. Polycystic ovary syndrome increases the risk of endometrial cancer in women aged less than 50 years: an Australian case-control study. Cancer Causes Control. 2010;21(12):2303-8.

4. Cobin $\mathrm{RH}$. Cardiovascular and metabolic risks associated with PCOS. Intern Emerg Med. 2013;8(Suppl 1):S61-4.

5. Karjula S, Morin-Papunen L, Franks S, Auvinen J, Järvelin MR, Tapanainen JS, Jokelainen J, Miettunen J, Piltonen TT. Population-based data at ages 31 and 46 show decreased HRQOL and life satisfaction in women with PCOS symptoms. J Clin Endocrinol Metab. 2020;105(6):1814-26.

6. Damone AL, Joham AE, Loxton D, Earnest A, Teede HJ, Moran LJ. Depression, anxiety and perceived stress in women with and without PCOS: a community-based study. Psychol Med. 2019;49(9):1510-20.

7. Insenser M, Escobar-Morreale HF. Application of proteomics to the study of polycystic ovary syndrome. J Endocrinol Invest. 2011;34(11):869-75.

8. Insenser M, Escobar-Morreale HF. Proteomics and polycystic ovary syndrome. Expert Rev Proteomics. 2013;10(5):435-47.

9. Searle BC, Pino LK, Egertson JD, Ting YS, Lawrence RT, MacLean BX, Villén J, MacCoss MJ. Chromatogram libraries improve peptide detection and quantification by data independent acquisition mass spectrometry. Nat Commun. 2018:9(1):5128.
10. Rotterdam ESHRE/ASRM-Sponsored PCOS Consensus Workshop Group. Revised 2003 consensus on diagnostic criteria and long-term health risks related to polycystic ovary syndrome. Fertil Steril. 2004;81(1):19-25.

11. Manousopoulou A, Al-Daghri NM, Sabico S, Garay-Baquero DJ, Teng J, Alenad A, Alokail MS, Athanasopoulos N, Deligeoroglou E, Chrousos GP, et al. Polycystic ovary syndrome and insulin physiology: an observational quantitative serum proteomics study in adolescent, normal-weight females. Proteomics Clin Appl. 2019;13(5):e1800184.

12. Mushtaq S, Ali T, Javed Q, Tabassum S, Murtaza I. N-acetyl cysteine inhibits endothelin-1-induced ROS dependent cardiac hypertrophy through superoxide dismutase regulation. Cell J. 2015;17(2):355-60.

13. Galazis N, Olaleye O, Haoula Z, Layfield R, Atiomo W. Proteomic biomarkers for ovarian cancer risk in women with polycystic ovary syndrome: a systematic review and biomarker database integration. Fertil Steril. 2012;98(6):1590-601.e1.

14. Mannerås-Holm L, Baghaei F, Holm G, Janson PO, Ohlsson C, Lönn $\mathrm{M}$, Stener-Victorin E. Coagulation and fibrinolytic disturbances in women with polycystic ovary syndrome. J Clin Endocrinol Metab. 2011;96(4):1068-76

15. Aye MM, Kilpatrick ES, Aburima A, Wraith KS, Magwenzi S, Spurgeon B, Rigby AS, Sandeman D, Naseem KM, Atkin SL. Acute hypertriglyceridemia induces platelet hyperactivity that is not attenuated by insulin in polycystic ovary syndrome. J Am Heart Assoc. 2014;3(1):e000706.

16. Ojeda-Ojeda M, Murri M, Insenser M, Escobar-Morreale HF. Mediators of low-grade chronic inflammation in polycystic ovary syndrome (PCOS). Curr Pharm Des. 2013;19(32):5775-91.

17. Duleba AJ, Dokras A. Is PCOS an inflammatory process? Fertil Steril. 2012;97(1):7-12.

18. Yu Y, Pieper R. Using proteomics to identify inflammation during urinary tract infection. Methods Mol Biol. 2019;2021:259-72.

19. Aziz M, Sidelmann JJ, Wissing ML, Faber J, Skouby SO. Endogenous thrombin potential in polycystic ovary syndrome: the association to body mass index, insulin resistance, and inflammation. Gynecol Endocrinol. 2015;31(9):720-4

20. Schmidt J, Weijdegård B, Mikkelsen AL, Lindenberg S, Nilsson L, Brännström M. Differential expression of inflammation-related genes in the ovarian stroma and granulosa cells of PCOS women. Mol Hum Reprod. 2014;20(1):49-58.

21. Liu M, Gao J, Zhang Y, Li P, Wang H, Ren X, Li C. Serum levels of TSP-1, NF-KB and TGF- $\beta 1$ in polycystic ovarian syndrome (PCOS) patients in northern China suggest PCOS is associated with chronic inflammation. Clin Endocrinol (Oxf). 2015;83(6):913-22

22. Levi M, van der Poll T. Inflammation and coagulation. Crit Care Med. 2010;38(2 Suppl):S26-34.

23. Schoenmakers SH, Reitsma PH, Spek CA. Blood coagulation factors as inflammatory mediators. Blood Cells Mol Dis. 2005;34(1):30-7.

24. Göbel K, Eichler S, Wiendl H, Chavakis T, Kleinschnitz C, Meuth SG. The coagulation factors fibrinogen, thrombin, and factor XII in inflammatory disorders - a systematic review. Front Immunol. 2018;9:1731.

25. Wang W, Meng ZQ, Shi FX. Yi Chuan. 2012;34(7):810-8.

26. Greer EL, Shi Y. Histone methylation: a dynamic mark in health, disease and inheritance. Nat Rev Genet. 2012;13(5):343-57.

27. Monteiro JB, Colón-Díaz M, García M, Gutierrez S, Colón M, Seto E, Laboy J, Flores I. Endometriosis is characterized by a distinct pattern of histone 3 and histone 4 lysine modifications. Reprod Sci. 2014;21(3):305-18.

28. Jefferson WN, Chevalier DM, Phelps JY, Cantor AM, Padilla-Banks E, Newbold RR, Archer TK, Kinyamu HK, Williams CJ. Persistently altered epigenetic marks in the mouse uterus after neonatal estrogen exposure. Mol Endocrinol. 2013;27(10):1666-77.

29. Jolly L, Lemarie J, Carrasco K, Popovic B, Derive M, Boufenzer A, Gibot S. Triggering Receptor Expressed on Myeloid cells-1: a new player in platelet aggregation. Thromb Haemost. 2017;117(9):1772-81.

30. Vázquez-Otero I, Rodríguez-Navedo Y, Vilá-Rivera K, Nieves-Plaza M, Morales-Ortiz J, Washington AV, Vilá LM. Association of soluble TREM-like transcript-1 with clinical features and patient reported outcomes in systemic lupus erythematosus. Eur J Rheumatol. 2018;5(4):244-8.

31. Morales-Ortíz J, Deal V, Reyes F, Maldonado-Martínez G, Ledesma N, Staback F, Croft C, Pacheco A, Ortiz-Zuazaga H, Yost CC, et al. Platelet-derived TLT-1 is a prognostic indicator in ALI/ARDS and prevents tissue damage in the lungs in a mouse model. Blood. 2018;132(23):2495-505. 
32. Glembotsky AC, Sliwa D, Bluteau D, Balayn N, Marin Oyarzún CP, Raimbault A, Bordas M, Droin N, Pirozhkova I, Washington V, et al. Downregulation of TREM-like transcript-1 and collagen receptor a2 subunit, two novel RUNX1-targets, contributes to platelet dysfunction in familial platelet disorder with predisposition to acute myelogenous leukemia. Haematologica. 2019;104(6):1244-55.

33. Derive M, Bouazza Y, Sennoun N, Marchionni S, Quigley L, Washington V, Massin F, Max JP, Ford J, Alauzet C, et al. Soluble TREM-like transcript-1 regulates leukocyte activation and controls microbial sepsis. J Immunol. 2012;188(11):5585-92.

\section{Publisher's Note}

Springer Nature remains neutral with regard to jurisdictional claims in published maps and institutional affiliations.
Ready to submit your research? Choose BMC and benefit from:

- fast, convenient online submission

- thorough peer review by experienced researchers in your field

- rapid publication on acceptance

- support for research data, including large and complex data types

- gold Open Access which fosters wider collaboration and increased citations

- maximum visibility for your research: over 100M website views per year

At BMC, research is always in progress.

Learn more biomedcentral.com/submissions 